\title{
PENGARUH PENGELUARAN PEMERINTAH DAERAH TERHADAP PERTUMBUHAN EKONOMI SOLO RAYA 2009-2018
}

Oleh:

\author{
Fernaldi Anggadha Ratno \\ Program Studi Ekonomi Syariah \\ Fakultas Ekonomi dan Bisnis Islam \\ IAIN Salatiga \\ Email: \\ anggadharatno@iainsalatiga.ac.id
}

\begin{abstract}
This quantitative dynamic panel research is aimed to find out the effect of Government Expenditure in forms of Local Government Expenditure towards the Economic Growth of Solo Raya in 2009-2018. The analysis uses autoregressive distributed-lag dynamic model which includes not only the current but also the lagged values of the explanatory variable, and one or more lagged values of the dependent variables. The result of the analysis shows that Direct Expenditure gives more 1.32E-07 percent significant effect to the Economic Growth in Solo Raya, so does the Economic Growth of the past one year. Both Direct and Indirect Expenditure of the past one year give additional effects to the Economic Growth. Based on the analysis, it is recommended for the government to more thoroughly and carefully count the number of government expenditures and pays more attention to the allocation of Direct Expenditure which is able to contribute and give significant effect to the economic growth of a region.
\end{abstract}

Key words: Economic Growth, Local Government Expenditure

\section{A. PENDAHULUAN}

Pertumbuhan ekonomi dapat merinci banyak hal, dengan melihat pertumbuhan ekonomi, kita dapat melihat secara kuantitatif seberapa maju tingkat ekonomi suatu Negara/Daerah. Pertumbuhan ekonomi sesungguhnya dapat menunjukkan angka yang meningkat dari tahun ke tahun, karena pertumbuhan ekonomi yang tinggi diperlukan guna mempercepat perubahan struktur perekonomian daerah menuju perekonomian yang berimbang dan dinamis (Bawuno, 2015). Pertumbuhan ekonomi dipengaruhi oleh beberapa faktor, antara lain: faktor sumber daya manusia, faktor sumber daya alam, faktor ilmu pengetahuan dan teknologi, faktor budaya dan faktor sumber daya modal. Berkaitan dengan faktor-faktor tersebut, pemerintahan di sebuah negara biasanya melakukan pembiayaan untuk mendukung kegiatan-kegiatan pemerintah yang bertujuan untuk memberdayakan serta memaksimalkan faktor-faktor yang berpengaruh terhadap pertumbuhan ekonomi tersebut. Artinya, pengeluaran pemerintah secara praktis akan mempengaruhi kegiatan-kegiatan perekonomian, dapat menciptakan proses pembangunan dan menambah kapasitas produk domestik. 
Indonesia memiliki aturan dan ketentuan dalam menetapkan kebijakan ekonomi, serta memiliki sejumlah instrumen yang mempengaruhinya. Dengan kebijakan makro ekonomi seperti memberlakukan atau mengubah kebijakan fiskal atau kebijakan lainnya, pemerintah dapat mengendalikan perekonomian menuju suatu komposisi output, stabilitas harga, kesempatan kerja dan perdagangan internasional yang lebih baik.

Besaran pengeluaran/belanja pemerintah menunjukkan banyaknya kegiatan pemerintah, pemerintah melakukan banyak sekali pengeluaran untuk membiayai kegiatan-kegiatannya. Pengeluaran tersebut bukan saja untuk menjalankan roda pemerintah sehari-hari akan tetapi juga untuk membiayai kegiatan perekonomian, dalam arti pemerintah harus menggerakkan dan merangsang kegiatan ekonomi secara umum. Tolok ukur penting dalam menentukan keberhasilan pembangunan ekonomi adalah pertumbuhan ekonomi yang menggambarkan suatu dampak nyata dari kebijakan pembangunan yang dilaksanakan. Pertumbuhan ekonomi dalam sistem pemerintahan daerah terindikasi dari peningkatan produksi barang dan jasa yang diukur melalui Produk Domestik Regional Bruto (PDRB). Berdasarkan data Badan Pusat Statistik (BPS) Kota Klaten (2019), pada tabel berikut dapat dilihat laju pertumbuhan ekonomi di Surakarta, Boyolali, Sukoharjo, Karanganyar, Wonogiri, Sragen, dan Klaten yang mengalami fluktuasi dari tahun 2009 sampai tahun 2014:

Tabel 1

Pertumbuhan Ekonomi Kawasan Solo Raya

\begin{tabular}{|c|l|c|c|c|c|c|c|c|c|c|c|}
\hline No & Kabupaten & 2009 & 2010 & 2011 & 2012 & 2013 & 2014 & 2015 & 2016 & 2017 & 2018 \\
\hline 1 & Surakarta & $5.90 \%$ & $5.94 \%$ & $6.04 \%$ & $6.12 \%$ & $5.89 \%$ & $4.58 \%$ & $5.44 \%$ & $5.35 \%$ & $5.70 \%$ & $5.74 \%$ \\
\hline 2 & Boyolali & $5.16 \%$ & $3.60 \%$ & $5.28 \%$ & $5.66 \%$ & $5.43 \%$ & $3.71 \%$ & $5.95 \%$ & $5.33 \%$ & $5.79 \%$ & $5.71 \%$ \\
\hline 3 & Sukoharjo & $4.76 \%$ & $4.65 \%$ & $4.59 \%$ & $5.03 \%$ & $5.01 \%$ & $3.96 \%$ & $5.68 \%$ & $5.71 \%$ & $5.75 \%$ & $5.79 \%$ \\
\hline 4 & Karanganyar & $5.54 \%$ & $5.42 \%$ & $5.50 \%$ & $5.82 \%$ & $5.38 \%$ & $5.55 \%$ & $5.05 \%$ & $5.40 \%$ & $5.77 \%$ & $5.97 \%$ \\
\hline 5 & Wonogiri & $4.73 \%$ & $5.87 \%$ & $2.24 \%$ & $5.87 \%$ & $4.36 \%$ & $4.58 \%$ & $5.39 \%$ & $5.25 \%$ & $5.31 \%$ & $5.41 \%$ \\
\hline 6 & Sragen & $6.01 \%$ & $6.09 \%$ & $6.53 \%$ & $6.60 \%$ & $6.64 \%$ & $3.45 \%$ & $6.05 \%$ & $5.77 \%$ & $5.97 \%$ & $5.75 \%$ \\
\hline 7 & Klaten & $4.24 \%$ & $1.73 \%$ & $1.96 \%$ & $5.54 \%$ & $5.79 \%$ & $4.52 \%$ & $5.29 \%$ & $5.17 \%$ & $5.34 \%$ & $5.46 \%$ \\
\hline \multicolumn{8}{c|}{ Sumber: Jawa Tengah dalam Angka; BPS Kota Klaten, 2019 }
\end{tabular}

Didukung oleh antisipasi dan perbaikan ekonomi, serta asumsi menurunnya suku bunga bank diharapkan kegiatan ekonomi sektor riil mulai bergerak, dan bisa meningkatkan laju pertumbuhan ekonomi suatu Negara, ataupun Daerah. Oleh sebab itu, Pemerintah melakukan berbagai pengeluaran yang berhubungan dengan pembelanjaan dan pembiayaan yang bertujuan membiayai kegiatan masyarakat di berbagai bidang.

Berkaitan dengan pengeluaran pemerintahan daerah, berdasarkan Berdasarkan Peraturan Menteri Dalam Negeri Nomor 52 Tahun 2015 tentang Pedoman Pengelolaan Keuangan Daerah (dikutip dalam Zahari, 2017), Pengeluaran Pemerintah dapat diklasifikasikan menjadi dua, yaitu Belanja Tidak Langsung dan Belanja Langsung. Berikut data Pengeluaran Pemerintah Daerah dalam bentuk Belanja Langsung dan Belanja Tidak Langsung di Surakarta, Boyolali, Sukoharjo, Karanganyar, Wonogiri, Sragen, dan Klaten: 
Tabel 2

Data Pengeluaran Pemerintah Kawasan Solo Raya

\begin{tabular}{|c|c|c|c|c|c|c|c|c|}
\hline \multirow{2}{*}{ Kabupaten } & \multicolumn{2}{|c|}{2012} & \multicolumn{2}{|c|}{2014} & \multicolumn{2}{|c|}{2016} & \multicolumn{2}{|c|}{2018} \\
\hline & $\mathrm{BL}$ & BTL & $\mathrm{BL}$ & BTL & $\mathrm{BL}$ & BTL & $\mathrm{BL}$ & BTL \\
\hline Surakarta & 396,277 & 748,894 & 624,210 & 890,221 & 764,196 & $1,083,731$ & 738,546 & $1,176,271$ \\
\hline Boyolali & 358,910 & 873,673 & 548,210 & $1,076,090$ & 735,238 & $1,415,727$ & 933,021 & $1,270,091$ \\
\hline Sukoharjo & 378,085 & 727,661 & 510,907 & 956,028 & 625,944 & $1,286,927$ & 874,422 & $1,175,739$ \\
\hline Karanganyar & 244,899 & 924,570 & 490,398 & $1,167,034$ & 573,375 & $1,479,208$ & 771,051 & $1,293,530$ \\
\hline Wonogiri & 375,152 & 955,909 & 478,913 & $1,145,036$ & 653,043 & $1,596,461$ & 886,433 & $1,360,427$ \\
\hline Sragen & 308,652 & 888,752 & 484,460 & $1,088,640$ & 679,859 & $1,511,097$ & 912,832 & $1,323,969$ \\
\hline Klaten & 338,505 & $1,096,104$ & 480,259 & $1,371,521$ & 490,776 & $2,004,135$ & $1,018,676$ & $1,954,442$ \\
\hline
\end{tabular}

Tabel 2 menunjukkan adanya perbedaan yang signifikan dalam jumlah pengeluaran yang dilakukan oleh pemerintah untuk tiap daerah setiap tahunnya. Secara umum, pengeluaran pemerintah dalam bentuk Belanja Tidak Langsung memiliki nilai dan persentase lebih besar daripada Belanja Langsung. Selain itu pada beberapa Daerah/Kabupaten selisih nilai dan persentase antara Belanja Tidak Langsung dan Belanja Tidak Langsung juga cukup signifikan, yang menunjukkan bahwa pengalokasian dana untuk setiap daerah berbeda-beda sesuai dengan tingkat kebutuhan dan kepentingannya. Misalnya: pengeluaran pemerintah untuk kabupaten Klaten pada tahun 2018; nilai BTL-nya sebesar 1,954,442 juta rupiah sedangkan BL-nya hanya sebesar 1,018,676 juta rupiah. Hal ini pula yang diduga mempengaruhi laju pertumbuhan ekonomi Solo Raya, walaupun perbedaan angka tersebut muncul dengan pertimbangan serta perhitungan tertentu.

Hipotesis bahwa pertumbuhan ekonomi tahun ini dipengaruhi oleh Belanja Langsung dan Belanja Tidak Langsung tahun ini dan tahun-tahun sebelumnya, serta pertumbuhan ekonomi tahun sebelumnya didasari oleh pemikiran bahwa pengeluaran pemerintah (government expenditure) adalah bagian dari kebijakan fiskal yang tercermin dalam Anggaran Pendapatan Belanja Negara (APBN) untuk Nasional dan Anggaran Pendapatan Belanja Daerah (APBD) untuk Daerah.

Untuk menganalisis pengaruh pengeluaran pemerintah daerah terhadap pertumbuhan ekonomi digunakan spesifikasi model regresi panel dinamis. Model regresi panel dinamis sangat tepat digunakan untuk menganalisa hubungan antara perubahan suatu besaran ekonomi dan kebijakan ekonomi di suatu saat dan pengaruhnya terhadap gejala dan perilaku ekonomi di saat yang lain, karena ketergantungan variabel dependen (dalam hal ini pertumbuhan ekonomi) terhadap yariabel independen (pengeluaran pemerintah) jarang terjadi secara instant, akan tetapi melibatkan selisih waktu (time lag).

Regresi data panel dinamis merupakan metode regresi yang menambahkan lag variabel dependen untuk dijadikan sebagai variabel independen (Nabilah \& Setiawan, 2016), model linier dinamis yang digunakan untuk menganalisis data panel dalam penelitian ini adalah model autoregressive distributed-lag, dengan asumsi bahwa pertumbuhan ekonomi tahun ini selain dipengaruhi oleh pengeluaran pemerintah tahun ini juga dipengaruhi oleh pengeluaran pemerintah tahun-tahun sebelumnya. Selain itu, diasumsikan pula bahwa pertumbuhan ekonomi tahun sebelumnya juga akan mempengaruhi pertumbuhan ekonomi tahun ini. 
Dari uraian di atas dapat dilihat bahwa untuk menjalankan pembangunan ekonomi yang ditujukan untuk kesejahteraan rakyat, pemerintah melakukan berbagai pengeluaran demi tercapainya laju pertumbuhan ekonomi yang kuat dan stabil.

\section{B. KAJIAN PUSTAKA}

\section{Pertumbuhan Ekonomi}

Pertumbuhan Ekonomi merupakan salah satu indikator dari keberhasilan pembanguanan ekonomi suatu daerah. Dimana pembangunan yang dilakukan pemerintah daerah dapat tepat sasaran maka Pertumbuhan ekonomi akan mengalami peningkatan. Bila pertumbuhan ekonomi daerah meningkat maka tingkat kesejahteraan masyarakat dan juga produktifitasnya pun semakin tinggi (Paseki, 2014). Sehingga pengangguran berkurang dan kemiskinan pun akan turun, dan dengan adanya pertumbuhan ekonomi maka diharapkan pendapatan masyarakat sebagai pemilik faktor produksi juga akan meningkat.

Perekonomian dianggap mengalami pertumbuhan jika seluruh balas jasa riil terhadap penggunaan faktor produksi pada tahun tertentu lebih besar dari pada tahun sebelumnya. Artinya, pertumbuhan ekonomi lebih menunjuk kepada perubahan yang bersifat kuantitatif (quantitative change) dan biasanya diukur dengan menggunakan data Produk Domestik Bruto $(G D P)$ atau pendapatan atau nilai akhir pasar (total market value) dari barang-barang akhir dan jasa-jasa (final goods and services) yang dihasilkan dari suatu perekonomian selama kurun waktu tertentu (biasanya satu tahun).

Pertumbuhan ekonomi merupakan suatu proses yang mencerminkan aspek dinamis dari suatu perekonomian mengambarkan bagaimana suatu perekonomian berkembang atau berubah dari waktu ke waktu (Susanti, Syechalad, \& Hamzah, 2018).

\section{Pengeluaran Pemerintah}

Pemerintah merupakan salah satu pelaku ekonomi yang semakin penting perannya dalam perekonomian modern. Aktivitas ekonomi yang dilakukan pemerintah ditunjukkan untuk perubahan struktur ekonomi oleh kebijakan fiskal melalui penetapan rencana anggaran penerimaan dan belanja negara. Secara teoritis pengeluaran pemerintah yang diperuntukkan bagi kepentingan umum dan kesejahteraan masyarakat, akan mendorong meningkatnya pendapatan perkapita yang semakin besar dari tahun ketahun (Sari, Syechalad, \& Majid, 2016). Berdasarkan Peraturan Menteri Dalam Negeri Nomor 52 Tahun 2015 tentang Pedoman Pengelolaan Keuangan Daerah (dikutip dalam Zahari, 2017), Belanja Pemerintah dikelompokkan menjadi 2 bagian.

a. Belanja tidak langsung, adalah bagian belanja yang dianggarkan tidak terkait langsung dengan pelaksanan program dan kegiatan. Seperti belanja pegawai berupa gaji dan tunjangan yang telah di tetapkan oleh undang-undang, belanja bunga, belanja hibah, belanja bantuan social, belanja bagi hasil kepada 
provinsi/kabupaten/kota dan pemerintah dasa, belanja bantuan keuangan dan belanja tak tersangka.

b. Belanja langsung, adalah belanja yang dianggarkan yang terkait secara langsung dengan pelaksanaan program dan kegiatan. Seperti belanja pegawai, belanja barang dan jasa, serta belanja modal untuk melaksanakan program dan kegiatan pemerintah daerah dan telah dianggarkan oleh pemerintah daerah.

Pengeluaran pemerintah termasuk pengeluaran berulang dan modal dapat meningkatkan pertumbuhan walaupun menyediakan infrastruktur penting termasuk transportasi, listrik, telekomunikasi, air dan sanitasi, pembuangan limbah, pendidikan dan kesehatan, pengeluaran ini dapat menghambat pertumbuhan (Mehrara, 2013). Perubahan dalam pengeluaran pemerintah dan pajak akan mempengaruhi tingkat pendapatan. Hal ini menimbulkan kemungkinan bahwa kebijakan fiskal dapat digunakan untuk menstabilkan perekonomian. Jika perekonomian berada dalam resesi, pajak harus dikurangi atau pengeluaran ditingkatkan untuk menaikkan output. Jika sedang berada dalam masa makmur (booming) pajak seharusnya dinaikkan atau pengeluaran pemerintah dikurangi agar kembali ke penggunaan tenaga kerja penuh.

\section{Pengeluaran Pemerintah Daerah dan Pertumbuhan Ekonomi}

Semua Negara di dunia telah sepakat bahwa untuk mengukur kesejahteraan ekonomi suatu bangsa, indikator yang digunakan adalah nilai produk nasional bruto per kapita. Semakin tinggi produk nasional bruto per kapita, semakin makmur negara yang bersangkutan (Sulistiawati, 2012).

Pertumbuhan ekonomi merupakan indikasi keberhasilan pembangunan ekonomi karena mencakup proses perubahan kondisi perekonomian suatu negara yang berkesinambungan menuju keadaan yang lebih baik. Pertumbuhan ekonomi dapat diartikan juga sebagai proses kenaikan kapasitas produksi suatu perekonomian yang diwujudkan dalam bentuk kenaikan pendapatan nasional.

Pertumbuhan ekonomi dipengaruhi oleh beberapa faktor, antara lain: faktor sumber daya manusia, faktor sumber daya alam, faktor ilmu pengetahuan dan teknologi, faktor budaya dan faktor sumber daya modal. Berkaitan dengan faktorfaktor tersebut, pemerintahan di sebuah negara biasanya melakukan pembiayaan untuk mendukung kegiatan-kegiatan pemerintah yang bertujuan untuk memberdayakan serta memaksimalkan faktor-faktor yang berpengaruh terhadap pertumbuhan ekonomi tersebut. Artinya, pengeluaran pemerintah secara praktis akan mempengaruhi kegiatan-kegiatan perekonomian, dapat menciptakan proses pembangunan dan menambah kapasitas produk domestik.

Dalam upaya mencapai pertumbuhan ekonomi yang tinggi diperlukan rumusan kebijakan makro ekonomi yang tepat yang mencakup kebijakan moneter dan kebijakan fiskal. Pertumbuhan PDB dipengaruhi oleh variabel belanja pemerintah, pajak, Indeks Harga Konsumen (IHK), kurs dan tingkat bunga Sertifikat Bank Indonesia (SBI). Variabel belanja pemerintah secara dominan masuk dalam indikator/variabel komponen dari kebijakan fiskal. Kontribusi dari kebijakan fiskal terhadap pertumbuhan PDB dengan variabel government spending 
(G) terbukti berpengaruh signifikan terhadap pertumbuhan PDB (Hadi, Sumari, \& Djapri, 2016).

Secara teoritis pengeluaran pemerintah yang diperuntukkan bagi kepentingan umum dan kesejahteraan masyarakat akan mendorong meningkatnya pendapatan perkapita yang semakin besar dari tahun ketahun. Peningkatan ini ditandai dengan naiknya Produk Domestik Bruto melalui bekerjanya efek pengganda. Pada gilirannya peningkatan Produk Domestik Bruto akan mempengaruhi besarnya penerimaan pemerintah dalam bentuk pajak, baik langsung maupun tidak (Sari, Syechalad, \& Majid, 2016).

Dari tujuan-tujuan tersebut di atas, dapat disimpulkan bahwa pengeluaran pemerintah akan mempunyai pengaruh dan peranan penting dalam memacu serta mendorong pertumbuhan ekonomi. Berarti pula bahwa pengeluaran pemerintah yang berbentuk belanja tidak langsung dan belanja langsung akan memberikan dampak secara parsial maupun simultan terhadap pertumbuhan ekonomi.

\section{METODE PENELITIAN}

Penelitian ini menggunakan jenis data kuantitatif dengan menggunakan data sekunder yaitu data PDRB (Produk Domestik Regional Bruto) dan data Pengeluaran Pemerintah Daerah di kawasan Solo Raya (Kota Surakarta, Kabupaten Klaten, Kabupaten Boyolali, Kabupaten Sukoharjo, Kabupaten Karanganyar, Kabupaten Sragen, dan Kabupaten Wonogiri) periode 2009-2018 (dalam satuan persen), dan data pengeluaran pemerintah yang terinci dalam data Belanja Langsung dan Belanja Tidak Langsung pemerintah kawasan Solo Raya dari tahun 2009-2018 (dalam satuan juta rupiah) yang bersumber dari Badan Pusat Statistik Kota Klaten.

Dalam penelitian ini, Belanja Tidak Langsung (BTL) merupakan variabel independen kesatu atau $\mathrm{X}_{1}$ dan Belanja Langsung (BL) menjadi $\mathrm{X}_{2}$ atau variabel independen kedua, sedangkan Pertumbuhan Ekonomi (PE) merupakan variabel dependen (Y).

Penelitian ini menggunakan teknik analisis regresi panel dengan model ekonometrika dinamis, karena struktur data panel melibatkan data runtut waktu (time series). Data panel adalah gabungan antara data silang (cross section) dan data runtut waktu (time series) dimana unit cross section yang sama diukur pada waktu yang berbeda. Dengan kata lain, data panel yaitu data dari beberapa individu sama yang diamati dalam kurun waktu tertentu. Artinya, jika terdapat $\mathrm{N}$ jumlah individu $(\mathrm{i}=1,2, \ldots, \mathrm{N})$ dan $\mathrm{T}$ periode waktu $(\mathrm{t}=1,2, \ldots, \mathrm{T})$ maka dengan data panel akan didapatkan total unit observasi sebanyak NT.

Untuk mengestimasi model regresi data panel dalam penelitian ini, model yang digunakan adalah Ordinary Least Square, yang kemudian dibandingkan dengan model regresi dinamis. Model regresi dinamis terdiri dari 2 (dua) model yaitu model autoregressive dan model distributed-lag. Model autoregressive yaitu model regresi yang melibatkan nilai variabel dependen pada waktu-waktu sebelumnya, sedangkan model distributed-lag yaitu model regresi yang melibatkan variabel independen tidak hanya pada saat ini (t), tapi juga pada waktu-waktu sebelumnya/(t-1), ((t-2), dst. 


\section{HASIL DAN PEMBAHASAN}

Terdapat tiga model data panel yaitu Common Effect Model, Fixed Effect Model, dan Random Effect Model (Falah, Mustafid \& Sudarno, 2016). Untuk memastikan model yang paling tepat digunakan, data dianalisa dengan menggunakan tiga metode/ pendekatan, yaitu Pooled/Panel Least Square (PLS) atau Common Effect yang merupakan metode paling sederhana, Fixed Effect atau Least Square Dummy Variable, dan Random Effect atau Generalized Least Square. Dengan asumsi bahwa variabel dependen PE-t (pertumbuhan ekonomi tahun ini) dipengaruhi oleh BTL (Belanja Tidak Langsung) dan BL (Belanja Langsung) tahun ini dan tahun-tahun sebelumya, maka variabel independen (X) yang akan digunakan dalam estimasi regresi pada penelitian ini adalah BTL, BTL (-1)it atau BTL satu tahun sebelumnya, BTL (-2)it atau BTL dua tahun sebelumnya dan BL, BL(-1)it atau BL satu tahun sebelumnya, BL(-2)it atau BL dua tahun sebelumnya. Model semacam ini disebut juga dengan model Regresi Data Panel Dinamis, atau metode regresi yang menambahkan lag pada variabel (Nabilah \& Setiawan, 2016); dengan asumsi data periode sekarang dipengaruhi oleh data-data pada periode sebelumnya. Dalam model ini terdapat lag atau selisih waktu sebanyak satu periode (t-1) dan dua periode (t-2). Maka, dalam analisis data panel ini variabel yang digunakan adalah variabel PE (Y), BTL, BTL (-1)it BTL (-2)it, dan BL, BL(-1)it, BL (-2)it. Variabel-variabel ini digunakan untuk mengestimasi model persamaan regresi, dengan $\beta$ untuk konstanta (c) dan $\varepsilon$ atau $\mu$ untuk residual atau error term.

Data panel yang telah disusun dala bentuk workfile dianalisis menggunakan 3 (tiga) metode yaitu common effect, fixed effect, dan random effect. Pertama, data panel diestimasi dengan variabel dependen PE (Y), dan variabel independen BTL $\left(\mathrm{X}_{1}\right)$ dan $\mathrm{BL}\left(\mathrm{X}_{2}\right)$ dengan Estimate Equation, dan hasil yang diperoleh sebagai berikut:

\section{Tabel 3}

\section{Hasil Analisis Regresi Estimasi dengan Variabel Dependen Pertumbuhan} Ekonomi

\begin{tabular}{llllll}
\hline Metode & Variable & Coefficient & Std. Error & t-Statistic & Prob. \\
\hline \multirow{3}{*}{ Common Effect } & C & 0.0613 & 0.0065 & 8.1762 & 0.0000 \\
& BTL & -0.00000002 & 0.00000001 & -1.7563 & 0.0712 \\
& BL & 0.00000001 & 0.00000002 & 0.7672 & 0.3476 \\
Fixed Effect & C & 0.0512 & 0.0090 & 5.5213 & 0.0000 \\
& BTL & 0.00000001 & 0.00000002 & 0.5610 & 0.3467 \\
& BL & -0.00000002 & 0.00000003 & -0.6936 & 0.4471 \\
& C & 0.0527 & 0.0071 & 8.6471 & 0.0000 \\
& BTL & -0.00000002 & 0.00000001 & -1.7626 & 0.0651 \\
& BL & 0.00000001 & 0.00000002 & 0.5413 & 0.4626 \\
\hline
\end{tabular}

Hasil analisis tersebut di atas meliputi nilai-nilai coefficient, standard error, $t$-Statistic, dan probability terjadinya masing-masing angka tersebut pada sebuah persamaan regresi. Hasil analisis menunjukkan bahwa dengan tiga metode yang digunakan, nilai probabilitas variabel $\mathrm{BL}\left(\mathrm{X}_{2}\right)$ tidak signifikan karena nilai probabilitasnya lebih besar pada tingkat signifikansi baik $1 \%, 5 \%$, maupun $10 \%$. 
Analisis estimasi dilakukan untuk memprediksi model yang baik atau yang paling layak digunakan dalam penelitian. Beberapa cara bisa dilakukan untuk mendapatkan model yang terbaik, salah satunya adalah dengan menambahkan sebuah atau sekelompok variabel baru. Persamaan regresi awal yang digunakan di atas adalah:

$$
P E_{i t}=\alpha+\beta_{1} \mathrm{BTL}+\beta_{2} \mathrm{BL}+\mu_{\mathrm{it}}
$$

Untuk menguji signifikansi model digunakan rumus (Sugiyono, 2014):

$$
\mathrm{F}=\frac{\frac{\mathrm{R}^{2}}{(k-1)}}{\left(1-R^{2}\right) /(n-k)}
$$

Kemudian digunakan nilai $\mathrm{R}^{2}$ dari metode Ordinary Least Square (OLS) yaitu nilai $\mathrm{R}^{2}$ metode OLS common effect sebesar 0.072 , dengan $\mathrm{k}=3$ (jumlah variabel) dan $\mathrm{n}=$ jumlah total observasi. Hasil yang diperoleh adalah $\mathrm{F}=1.62$, sedangkan nilai $\mathrm{F}$ tabel adalah 2.84. Jika $\mathrm{F}>\mathrm{F}_{\text {tabel }}$, maka $\mathrm{H}_{0}$ ditolak yaitu $\beta_{2}=\beta_{3}=\cdots=\beta_{k}=0$; $\mathrm{H}_{1}$ : tidak semua koefisien slop sama dengan nol. Apabila nilai $\mathrm{F}$ dan $\mathrm{R}^{2}$ rendah maka bisa dikatakan pengaruh regresor (BTL dan BL) terhadap regresan (PE) juga kecil, begitu juga sebaliknya. Oleh karena itu dilakukan langkah perbaikan terhadap model, yaitu dengan menambahkan variabel-variabel yang telah diasumsikan sebelumnya.

Model dinamis autoregressive distributed-lag dalam penelitian ini menggunakan asumsi bahwa PE (pertumbuhan ekonomi) tahun ini dipengaruhi oleh BTL dan BL tahun ini, BTL dan BL tahun-tahun sebelumnya, dan PE satu tahun sebelumnya. Maka, persamaan regresi yang digunakan adalah:

$$
P E_{i t}=\alpha+\beta_{1} \mathrm{BTL}+\beta_{2} \mathrm{BL}+\beta_{3} \mathrm{BTL}_{(\mathrm{t}-1)}+\beta_{4} \mathrm{BL}_{(\mathrm{t}-1)}+\beta_{5} \mathrm{BTL}_{(\mathrm{t}-2)}+\beta_{6} \mathrm{BL}_{(\mathrm{t}-2)}+\beta_{7} \mathrm{PE}_{(\mathrm{t}-1)}+\mu_{\mathrm{it}}
$$

Dengan persamaan regresi dilakukan analisis estimasi dengan menggunakan metode common effect dan fixed effect. Metode random effect tidak dapat diterapkan pada model analisis data panel dinamis ini karena jumlah cross-section pada penelitian ini sama dengan jumlah parameter yang akan diestimasi, yaitu 7 (tujuh). Untuk metode random effect model dinamis, jumlah cross section harus lebih besar daripada jumlah parameter yang akan diestimasi.

Informasi dari hasil analisis data panel model dinamis ini dapat digunakan untuk menguji signifikansi model. Ada beberapa cara yang bisa dilakukan, antara lain:

a. Dengan melihat informasi hasil analisis estimasi seperti melihat nilai $\mathrm{R}^{2}$. Nilai $\mathrm{R}^{2}$ menunjukkan kemampuan model untuk menjelaskan hubungan antara variabel independen dan variabel dependen. Nilai $R^{2}$ akan selalu berada di antara 0 dan 1 . Artinya, semakin besar nilai $\mathrm{R}^{2}$ (semakin mendekati 1) maka semakin besar pula kemampuan variabel independen menjelaskan pengaruhnya terhadap variabel dependen. Pada tabel berikut dapat dilihat bahwa nilai $\mathrm{R}^{2}$ model fixed effect lebih besar daripada nilai $\mathrm{R}^{2}$ model common effect. 


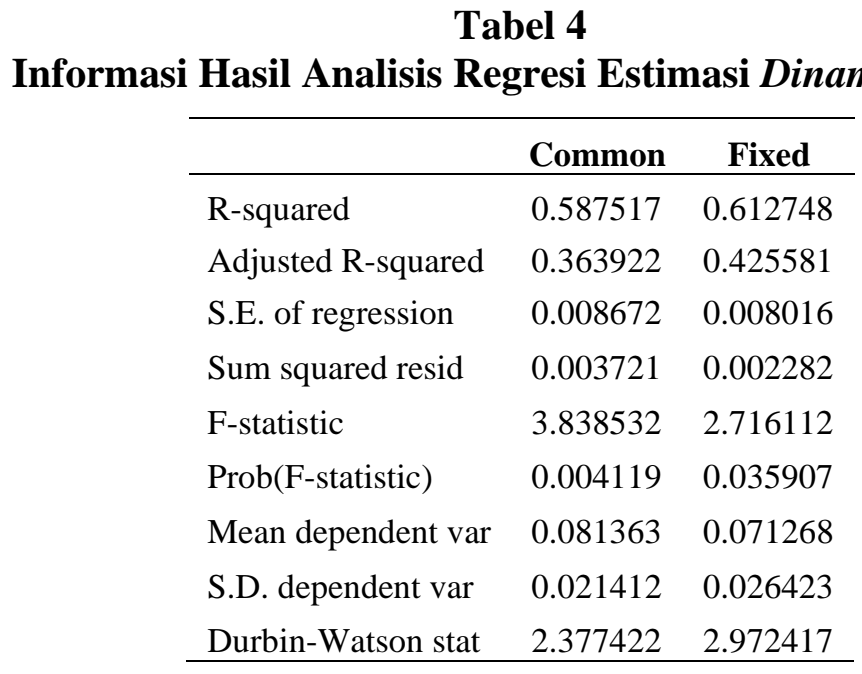

b. Membandingkan nilai $\mathrm{F}_{\text {ratio }}$ dengan nilai $\mathrm{F}_{\text {tabel }}$. Setelah melakukan analisis estimasi dengan dua model, yaitu model $O L S$ dan model dinamis, maka dapat dilakukan penghitungan nilai $\mathrm{F}_{\text {ratio }}$. Nilai $\mathrm{F}_{\text {ratio }}$ dapat dihitung dengan rumus (Gujarati, 2012):

$$
F=\frac{\frac{\left(\mathrm{R}^{2} \text { new }-\mathrm{R}^{2} \mathrm{old}\right)}{\text { jumlah regresor baru }}}{\left(1-\mathrm{R}^{2} \text { new }\right) /(\mathrm{n}-\text { jumlah parameter model baru })}
$$

Nilai $\mathrm{R}^{2}$ model $O L S$ sebesar 0.072 , sedangkan nilai $\mathrm{R}^{2}$ model dinamis sebesar 0.58. Jumlah regresor baru $=5$, dan jumlah parameter model baru $=7$. Maka, nilai $\mathrm{F}$ yang diperoleh dari hasil perhitungan adalah 8.56. Apabila nilai $\mathrm{F}_{\text {hitung }}$ lebih besar daripada nilai $\mathrm{F}_{\text {tabel }}$, maka model yang digunakan adalah model yang baru (model dinamis), sedangkan apabila nilai $\mathrm{F}_{\text {hitung }}$ lebih kecil daripada nilai $\mathrm{F}_{\text {tabel }}$, maka model yang digunakan adalah model $O L S$ (Ordinary Least Square). Nilai $\mathrm{F}_{\text {tabel }}$ diketahui 3.25, dan nilai $\mathrm{F}_{\text {hitung }} 8.56>$ 3.25 , artinya model dinamis lebih tepat digunakan dalam analisis data panel ini.

c. Dengan memasukkan nilai data ke dalam persamaan. Misalnya: menghitung angka persentase perkembangan ekonomi Kota Klaten pada tahun 2009, atau Kabupaten Wonogiri pada tahun 2018 dengan menggunakan persamaan regresi hasil estimasi. Model yang baik adalah model yang angka prediksinya mendekati kenyataan. PE kota Surakarta 2018 apabila dihitung dengan persamaan regresi model dinamis hasil analisis estimasi, akan diperolah hasil PE Surakarta 2018 adalah 5.81\% sedangkan nilai kenyataannya 5.74\%.

Uji kelayakan model menunjukkan hasil bahwa model dinamis lebih tepat karena $F_{\text {hitung }}>\mathrm{F}_{\text {tabel }}$. Langkah berikutnya adalah menentukan model yang lebih tepat digunakan antara common effect dengan fixed effect. Untuk itu, pengujian yang dapat digunakan adalah uji Chow.

Uji Chow bertujuan untuk membandingkan antara model Common Effect dan Fixed Effect. Uji ini dilakukan dengan membandingkan perhitungan $\mathrm{F}_{\text {hitung }}$ dengan $\mathrm{F}_{\text {tabel }}$. Perbandingan dipakai apabila hasil $\mathrm{F}_{\text {hitung }}$ lebih besar dari $\mathrm{F}_{\text {tabel }}$ maka $\mathrm{H}_{0}$ 
ditolak yang berarti model yang paling tepat digunakan adalah Fixed Effect Model. Jika $\mathrm{F}_{\text {hitung }}$ lebih kecil dari $\mathrm{F}_{\text {tabel }}$ maka $\mathrm{H}_{0}$ diterima dan model yang digunakan adalah Common Effect model. Untuk mendapatkan $\mathrm{F}_{\text {hitung }}$ bisa digunakan rumus:

$$
F=\frac{\frac{\mathrm{SSE}_{1}-\mathrm{SSE}_{2}}{(\mathrm{n}-1)}}{\frac{\mathrm{SSE}}{(\mathrm{nt}-\mathrm{n}-\mathrm{k})}}
$$

Yang merupakan rasio dari selisih antara Sum Square Error model Common Effect ( $\left.\mathrm{SSE}_{1}\right)$ dengan Sum Square Error model Fixed Effect $\left(\mathrm{SSE}_{2}\right)$ terhadap jumlah cross section: 7 (n), dibagi dengan Sum Square Error model Fixed Effect $\left(\mathrm{SSE}_{2}\right)$ terhadap selisih dari Jumlah cross section x jumlah time series:70 (nt) dan Jumlah variabel independent:2 $(k)$

Dengan rumus di atas nilai $F_{\text {hitung }}$ yang dihasilkan sebesar 1.02, sedangkan dengan rumus FINV (prob, df1, df2) dalam MS Excel nilai F tabel yang diperoleh adalah 2.65 (dengan probabilitas 5\%, degree of freedom 1: 2, dan degree of freedom 2: 39). Hipotesis dalam uji Chow adalah $\mathrm{H}_{0}$ : Common Effect Model dan $\mathrm{H}_{1}$ : Fixed Effect Model. Dasar penolakan terhadap hipotesis ini adalah dengan membandingakan nilai $\mathrm{F}_{\text {hitung }}$ dengan $\mathrm{F}_{\text {tabel }}$. Apabila nilai $\mathrm{F}_{\text {hitung }}$ lebih besar dari nilai $\mathrm{F}_{\text {tabel }}$ maka $\mathrm{H}_{0}$ ditolak, yang berarti model yang paling tepat digunakan adalah Fixed Effect. Sebaliknya, apabila nilai $\mathrm{F}_{\text {hitung }}$ lebih kecil dari nilai $\mathrm{F}_{\text {tabel }}$ maka $\mathrm{H}_{1}$ diterima, dan model yang lebih tepat digunakan adalah model Common Effect. Uji Chow dalam penelitian ini menunjukkan bahwa model Common Effect lebih tepat digunakan $(1.02<2.65)$.

Dengan EViews 8, pengujian bisa dilakukan dengan menggunakan fasilitas Redundant Fixed Effect-Likelihood Ratio, yang juga dilakukan dengan membandingkan hasil analisis estimasi metode fixed effect dengan hasil analisis estimasi metode common effect. Dari hasil pengujian dapat diketahui bahwa nilai probabilitas Cross-section $F$ sebesar 0.24 (24\%) dan lebih besar atau tidak signifikan terhadap $\alpha=5 \%$. Ini berarti bahwa model yang lebih tepat digunakan adalah model Common Effect.

Berdasarkan pengujian yang telah dilakukan tersebut, hasil yang diperoleh menunjukkan bahwa model dinamis autoregressive distributed-lag dengan metode common effect lebih tepat untuk digunakan. Metode ini digunakan dengan asumsi bahwa nilai persentase pertumbuhan ekonomi individu $\mathrm{i}$ pada tahun $\mathrm{t}\left(\mathrm{Y}_{i t}\right)$ dipengaruhi oleh nilai $\mathrm{BL}$ dan $\mathrm{BL}$ individu tersebut pada tahun $\mathrm{t}$, satu tahun sebelumnya (BTL ${ }_{i t-1}$ dan $\mathrm{BL}_{i(t-1)}$, dua tahun sebelumnya (BTLit-2 dan $\mathrm{BL}_{i t-2}$ ), dan juga dipengaruhi oleh $\mathrm{PE}$ tahun sebelumnya $\left(\mathrm{PE}_{i t-1}\right)$. Nilai koefisien regresi yang diperoleh sebagai berikut: 


\section{Tabel 5}

Hasil Analisis Data Panel Autoregressive Distributed-Lag

\begin{tabular}{lllll}
\multicolumn{2}{l}{ Dependent } & Variable: PE \\
Variable & Coefficient & Std. Error & t-Statistic & Prob. \\
\hline C & 0.04231 & 0.022142 & 4.142731 & 0.0010 \\
BTL & -0.0000000045 & 0.0000000211 & -0.13722 & 0.5118 \\
BL & -0.0000000631 & 0.0000000412 & -3.22731 & 0.0315 \\
BTL(-1) & 0.0000000115 & 0.0000000273 & 1.73211 & 0.1729 \\
BL(-1) & 0.0000000417 & 0.0000000141 & 2.524432 & 0.0113 \\
BTL(-2) & -0.0000000413 & 0.0000000100 & -1.33291 & 0.1431 \\
BL(-2) & -0.0000000520 & 0.0000000191 & -2.39271 & 0.0195 \\
PE(-1) & 0.661585 & 0.271129 & 1.324429 & 0.0062 \\
\hline & & & & \\
R-squared & 0.857517 & Durbin-Watson stat 3.377422 \\
\hline
\end{tabular}

Berdasarkan Tabel 5 maka persamaan regresi yang diperoleh adalah sebagai berikut:

$$
\begin{aligned}
\mathrm{PE}= & 0.04-4.51 \mathrm{e}-09 * \mathrm{BTL}-6.316 \mathrm{e}-08 * \mathrm{BL}+1.15 \mathrm{e}-08 * \mathrm{BTL}(-1)+4.17 \mathrm{e}-08 * \mathrm{BL} \\
& (-1)-4.13 \mathrm{e}-08 * \mathrm{BTL}(-2)-5.2 \mathrm{e}-08 * \mathrm{BL}(-2)+0.66 * \mathrm{PE}(-1) \mathrm{R}^{2}=0.85
\end{aligned}
$$

Keterangan

$\mathrm{PE}_{\mathrm{it}}$

BTL $_{\mathrm{t}-1} \quad$ : Belanja Tidak Langsung individu ke $i$ tahun sebelumnya

BLt-1 : Belanja Langsung individu ke $i$ tahun sebelumnya

BTL $L_{-2} \quad$ : Belanja Tidak Langsung individu ke $i$ dua tahun sebelumnya

$\mathrm{BL}_{\mathrm{t}-2} \quad$ : Belanja Langsung individu $i$ dua tahun sebelumnya

$\mathrm{PE}_{\mathrm{it}-1} \quad$ : Pertumbuhan Ekonomi individu $i$ tahun sebelumnya

Persamaan regresi tersebut dapat diinterpretasikan sebagai berikut:

a. Konstanta/intersep sebesar 0.04 secara matematis menyatakan bahwa jika nilai variabel bebas/independen BTL dan BL nol maka nilai PE adalah 0.04 atau 4\%. Berdasarkan kajian teoritis terkait dengan nilai konstanta, nilai konstanta tidak selalu dapat atau perlu diinterpretasikan. Artinya, variabel independen yang diasumsikan bernilai nol adalah tidak mungkin, karena pengukuran variabel independen dengan menggunakan skala likert 1 sampai 5 , variabel independen tersebut tidak mungkin bernilai nol karena skala likert terendah yang digunakan adalah 1 .

b. Koefisien regresi variabel yang bernilai positif menunjukkan bahwa variabel independen tersebut mempunyai pengaruh positif terhadap variabel dependen (PE), dan sebaliknya yang bernilai negatif menunjukkan bahwa variabel independen tersebut mempunyai pengaruh negatif terhadap variabel dependen (PE). Koefisien variabel independen tersebut juga menunjukkan 
bahwa peningkatan jumlah variabel independen tersebut akan menyebabkan naik atau turunnya persentase pertumbuhan ekonomi.

Berdasarkan hasil analisis regresi data panel dengan model dinamis autoregressive distributed-lag dengan metode common effect diperoleh persamaan regresi:

$$
\begin{aligned}
\mathrm{PE}= & 0.04-4.51 \mathrm{e}-09 * \mathrm{BTL}-6.316 \mathrm{e}-08 * \mathrm{BL}+1.15 \mathrm{e}-08 * \mathrm{BTL}(-1)+4.17 \mathrm{e}-08 * \mathrm{BL}(- \\
& 1)-4.13 \mathrm{e}-08 * \mathrm{BTL}(-2)-5.2 \mathrm{e}-08 * \mathrm{BL}(-2)+0.66 * \mathrm{PE}(-1) \mathrm{R}^{2}=0.85
\end{aligned}
$$

Persamaan tersebut berfungsi sebagai pedoman untuk melihat pengaruh pengeluaran pemerintah dalam bentuk Belanja Tidak Langsung dan Belanja Langsung terhadap variabel dependen yaitu Pertumbuhan Ekonomi (PE). Nilai koefisien regresi positif diartikan bahwa variabel independen berpengaruh positif terhadap variabel dependen, yang artinya peningkatan variabel independen akan meningkatkan variabel dependen dan apabila nilai variabel independen negatif maka variabel independen berpengaruh negatif terhadap variabel dependen, yang artinya peningkatan variabel independen akan menurunkan nilai variabel dependen.

Pada Tabel 5 yang berisi hasil analisis data panel dengan model dinamis autoregressive distributed-lag dapat diinterpretasikan bahwa jika BTL ditambah sejumlah 1 juta rupiah, maka PE akan turun sebesar 4.51e-09 persen. Sementara itu jika BL ditambah sejumlah 1 juta rupiah maka PE juga akan menurun sebesar 6.31e-08 persen. Pertumbuhan ekonomi akan meningkat $1.15 \mathrm{e}-08$ persen apabila BTL (-1) bertambah 1 juta rupiah, sedangkan apabila BL (-1) bertambah 1 juta rupiah maka PE akan meningkat $4.17 \mathrm{e}-08$ persen. Begitu pula untuk variabelvariabel independen lainnya.

Dalam analisis regresi model dinamis, BTL, BL, BTL (-1), BL (-1), BTL (2), dan BL (-2) merupakan variabel jangka pendek, sedangkan variabel jangka panjang dapat diperoleh dengan memperhitungkan nilai dari koefisien harapan (coefficient of expectation), yaitu perbedaan antara keadaan sebenarnya dengan keadaan yang diharapkan atau dilambangkan dengan $\lambda$. Koefisien harapan dalam model regresi dinamis ini adalah koefisien PE (-1). Jadi, koefisien regresi jangka panjang dari variabel-variabel di atas dapat dihitung dengan menggunakan rumus $\alpha_{1} / \lambda$ dengan hasil sebagai berikut:

Koefisien jangka panjang variabel:

$$
\begin{array}{ll}
\text { BTL } & =-4.51 \mathrm{E}-09 / 0.49=-8.16 \mathrm{E}-09 \mathrm{BL}=-5.65 \mathrm{E}-08 / 0.49=-10.58 \mathrm{E}-08 \\
\text { BTL }(-1) & =1.15 \mathrm{E}-08 / 0.49=5.15 \mathrm{E}-08 \\
\text { BL }(-1) & =4.17 \mathrm{E}-08 / 0.49=2.68 \mathrm{E}-07 \\
\text { BTL }(-2) & =-4.13 \mathrm{E}-08 / 0.49=-6.71 \mathrm{E}-08 \\
\text { BTL }(-2) & =-5.2 \mathrm{E}-08 / 0.49=-2.85 \mathrm{E}-07
\end{array}
$$

Secara keseluruhan, koefisien jangka panjang menunjukkan bahwa dalam jangka pendek dan jangka panjang arah pengaruh semua variabel sama. Artinya, jika BTL ditambah sejumlah 1 juta rupiah, maka dalam jangka pendek PE akan turun sebesar 4.51e-09 persen dan dalam jangka panjang akan turun 8.16E-09 persen. Sementara itu jika BL ditambah sejumlah 1 juta rupiah maka dalam jangka panjang PE juga akan menurun sebesar $10.58 \mathrm{E}-08$ persen. Dalam jangka panjang, Pertumbuhan Ekonomi akan meningkat 5.15E-08 persen apabila BTL (-1) 
bertambah 1 juta rupiah, sedangkan apabila BL (-1) bertambah 1 juta rupiah maka PE akan meningkat 2.68E-07 persen.

\section{E. SIMPULAN}

Berdasarkan hasil analisis data maka bisa disimpulkan bahwa:

a. Pertumbuhan Ekonomi di Kawasan Solo Raya dipengaruhi oleh Belanja Tidak Langsung Pemerintah Daerah. Pengaruh yang positif terhadap variabel Pertumbuhan Ekonomi (PE) ditunjukkan oleh variabel Belanja Tidak Langsung satu tahun sebelumnya (BTL-1), sedangkan Belanja Tidak Langsung tahun ini (BTL) dan Belanja Tidak Langsung dua tahun sebelumnya (BTL-2) memberikan pengaruh negatif terhadap Pertumbuhan Ekonomi. Hal tersebut sejalan dengan penelitian yang dilakukan oleh Wahyudi (2014).

b. Pertumbuhan Ekonomi di Kawasan Solo Raya dipengaruhi oleh Belanja Langsung Pemerintah Daerah. Pengaruh yang positif terhadap variabel Pertumbuhan Ekonomi (PE) ditunjukkan oleh variabel Belanja Langsung satu tahun sebelumnya BL(-1), sedangkan Belanja Langsung tahun ini (BL) dan Belanja Tidak Langsung dua tahun sebelumnya BL(-2) memberikan pengaruh negatif terhadap Pertumbuhan Ekonomi.

Hasil analisis data juga menunjukkan bahwa variabel Belanja Langsung berpengaruh signifikan terhadap variabel Pertumbuhan Ekonomi (PE) di kawasan Solo Raya sedangkan variabel Belanja Tidak Langsung tidak menunjukkan pengaruh yang signifikan terhadap Pertumbuhan Ekonomi, hal tersebut sejalan dengan penelitian yang dilakukan oleh Pambudi (2014). Selain itu, pengaruh yang positif dan signifikan juga ditunjukkan oleh variabel Pertumbuhan Ekonomi tahun sebelumnya. 


\section{DAFTAR PUSTAKA}

Badan Pusat Statistik. (2019). Jawa Tengah Dalam Angka 2019. Klaten: Badan Pusat Statistik Kota Klaten Jawa Tengah.

Bawuno, Eunike Elisabeth. (2015). Pengaruh Investasi Pemerintah Dan Tenaga Kerja Terhadap Pertumbuhan Ekonomi di Kota Manado. Jurnal Berkala Ilmiah Efisiensi, 15 (04), 245-254.

Falah, Bayyina Zidni., Mustafid., Sudarno. (2016). Model Regresi Data Panel Simultan Dengan Variabel Indeks Harga yang Diterima dan yang Dibayar Petani. Jurnal Gaussian, 5 (4), 611-621.

Ginting, Ari Mulianta., Dewi, Galuh Prila. (2013). Pengaruh Pertumbuhan Ekonomi dan Pertumbuhan Sektor Keuangan Terhadap Pengurangan Kemiskinan di Indonesia. Jurnal Ekonomi \& Kebijakan Publik, 4 (2), $117-$ 130.

Gujarati. (2012). Dasar-dasar Ekonometrika. Yogyakarta: Pustaka Pelajar.

Hadi, Arijo., Sumari, Datumaya Wahyudi., Djapri Suparman. (2016). Bauran Kebijakan Fiskal-Moneter dan Dampaknya Bagi Anggaran Pertahanan. Jurnal Pertahanan, 6 (3), 145-170.

Mehrara, Mohsen. (2013). Government Expenditure and Economic Growth in Iran. International Letters of Social and Humanistic Sciences, 11, 76-83.

Nabilah, Dessy., \& Setiawan. (2016). Pemodelan Pertumbuhan Ekonomi Indonesia Menggunakan Data Panel Dinamis dengan Pendekatan Generalized Method of Moment Arellano-Bond. Jurnal Sains dan Seni ITS, 5 (2), 205-210.

Pambudi, Eko Wicaksono. (2013). Analisis Pertumbuhan Ekonomi dan FaktorFaktor Yang Mempengaruhi (Kabupaten/Kota di Provinsi Jawa Tengah). Diponegoro Journal Of Economics, 2(2), 1-11.

Paseki, Meilen Greri. (2014). Pengaruh Dana Alokasi Umum Dan Belanja Langsung Terhadap Pertumbuhan Ekonomi Dan Dampaknya Terhadap Kemiskinan Di Kota Manado Tahun 2004-2012. Jurnal Berkala Ilmiah Efisiensi, 14(3), 30-42.

Sari, Mutia, Syechalad, Mochammad Nur., Majid, Sabri Abdul. (2016). Pengaruh Investasi, Tenaga Kerja dan Pengeluaran Pemerintah Terhadap Pertumbuhan Ekonomi di Indonesia. Jurnal Ekonomi dan Kebijakan Publik, 3 (2), 109115.

Sugiyono. (2014). Metode Penelitian Kuantitatif Kualitatif dan R\&D. Bandung: Alfabeta

Sulistiawati, Rini. (2012). Pengaruh Investasi terhadap Pertumbuhan Ekonomi dan Penyerapan Tenaga Kerja Serta Kesejahteraan Masyarakat di Provinsi di Indonesia. Jurnal Ekonomi Bisnis dan Kewirausahaan, 3 (1), 29-50. 
Susanti, Hewi., Syechalad, Mochammad Nur., Hamzah, Abubakar. (2017). Analisis Pengaruh Pertumbuhan Ekonomi Dan Pengeluaran Pemerintah Aceh Terhadap Pendapatan Asli Daerah Prov Aceh Setelah Tsunami. Jurnal Ekonomi dan Kebijakan Publik Indonesia, 4 (1), 1-12.

Wahyudi, Rudi. (2014). Analisis Belanja Pemerintah Dan Pertumbuhan Ekonomi Terhadap Tingkat Kemiskinan di Aceh. Jurnal Ilmu Ekonomi, 2 (3), 49-59.

Zahari, Muhammad. (2017). Pengaruh Pengeluaran Pemerintah Terhadap Pertumbuhan Ekonomi di Provinsi Jambi. Ekonomis: Jurnal of Economics and Business, 1 (1), 180-196. 